\title{
Clinical Study of Obestatin Hormone and its Relation to Diabetes Mellitus
}

\author{
Thikra A. Allwsh \\ Department of Chemistry \\ College of Science \\ University of Mosul
}

\author{
Jehan A. Mohammad \\ Department of Clinical Laboratory Science \\ College of Pharmacy \\ University of Mosul
}

(Received 23/9/2012;Accepted 28/1/2013)

\begin{abstract}
The research included an estimation of the concentration of obestatin hormone level in diabetic patients (Type I and Type II) and control.

The results demonstrated that the normal mean of obestatin hormone in serum was $(306.54 \pm 3.0 \mathrm{pg} / \mathrm{ml})$ in control for both sexes, with the ages range between (less or equal to 15 - more or equal to 55) year.

The results demonstrated a significant decrease in the level of obestatin hormone in serum of type I and type II diabetic patients compared to control, and between types I \& II diabetic patients.

The data showed that the level of obestatin hormone was not affected by age and sex, in control and diabetic patients, while showed a significant decrease according to body mass index (BMI) in control and diabetic patients (Type I and II). A significant gradual decrease in the concentration of obestatin as glucose concentration increases in diabetic patients was also observed.

The results showed a significant increase of adiponectin concentration between type I diabetic patient compared to type II, control, and a significant decrease in the concentration of adiponectin in diabetic patients (type II) compared with control.

Correlation coefficients of obestatin hormone with some biochemical parameters of control and diabetic patients showed that obestatin hormone has a significant negative correlation with glucose, HOMA-IR, total cholesterol and LDL-C.

Also, there was a significant positive correlation with HDL-C and adiponectin in control and diabetic patients (type I and II).

The result showed that obestatin hormone has a significant negative correlation with insulin, VLDL-C, total lipids in type II diabetic patients. Also, with triglyceride in control and type II diabetic patient.

It was concluded that low level of obestatin hormone index is a serious risk of diabetes mellitus and a major role for obestatin in diabetes mellitus type II. Moreover, the level could be used as a marker for diabetes mellitus and its role in obesity.
\end{abstract}

Keywords: Obestatin hormone, adeponectin hormone, diabetes, biochemical parameters, insulin resistance. 


\section{دراسة سريرية لهرمون الأوبستاتين وعلاقته بداء السكر A}

الأول والثالف والأصحاء. تقدير تركيز مستوى هرمون الأوبستاتين في المرض المصابين بداء اللسكر من النوعين بينت النتائج أن المعل الطبيعي لهرمون الأوبستاتين في مصل الدم كلن ( 306.54 3.

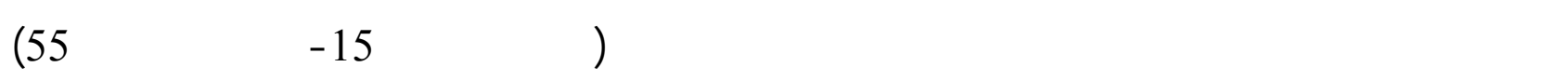
سنة.

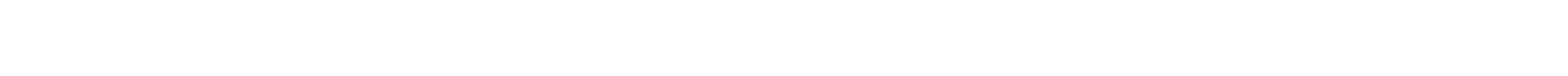

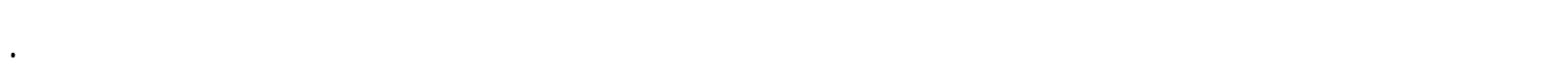

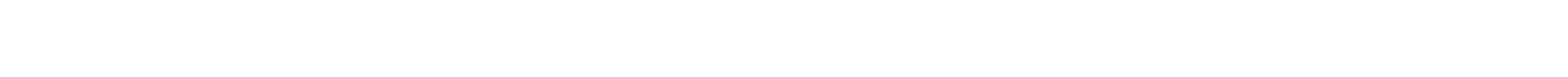

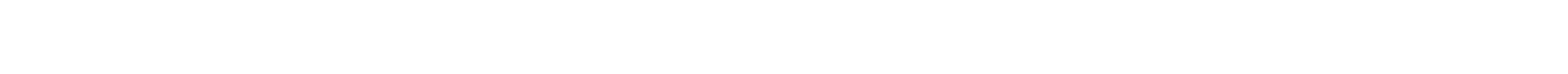
الأول والثاني وانخفاض معنوي تدريجي لتركيز الأوبستانين عند ازيياد تركيز الكلوكوز في مرضغ البه داء للسكر.

لوظظ أيضا وجود زياة معنوية في معل تركيز الأيبونكتنن بين النوع الأول مقارنة مع النوع الثالي لمرض داء للسكر والأصحاء، وانغفاض معنوي في تركيز الأيبونكتين في مرضن داء داء للسكر(النوع الثاني) مقارنة مع الأصحاء. كما دبست العلاقة بين هرمون الأوبستاتين وبعض المتغيرات الكيموحيوية للأصحاء ومرضف داء

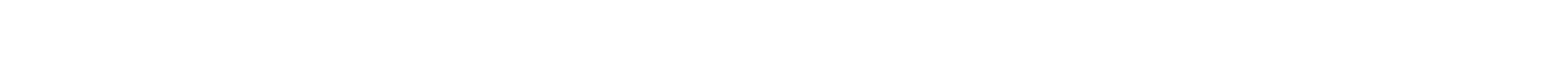
مقاومة الأنسولين، الكولسترول الكلي والبروتين الدهني الوطلئ الكثلفة للكوليستيرول.

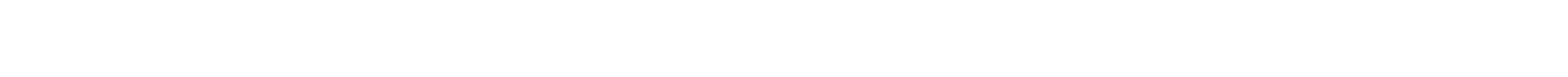
في كل من الأصحاء ومرضف السكري بنوعيه الأول والثاني.

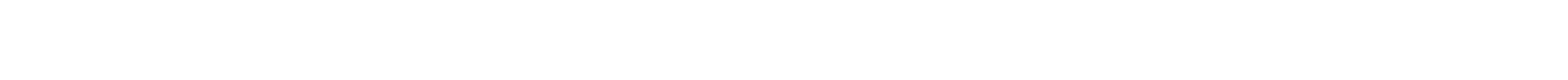
الوطلئ الكثلفة جدا للكوليستيرول، الدهون الكلية في مرض المضنك السكري من النوع الثاني ومع الكليسيريدات

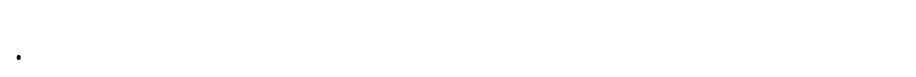

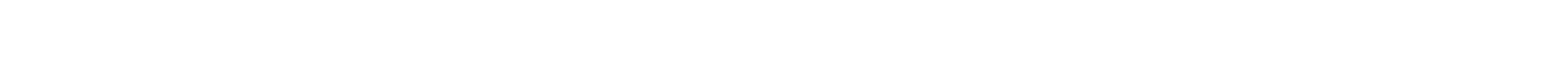

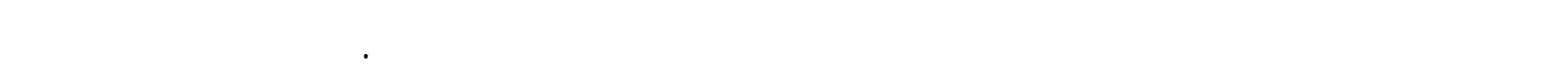
السمنة. الكاملت الدالة: هرمون الأوبستاتين، هرمون الأسيبونيكتن، داء السكر، المتغيرات الكيموحيوية، مقاومة الأنسولين. 


\section{INTRODUCTION}

Diabetes mellitus is a systemic, chronic metabolic disease characterized by hyperglycemia, dyslipidemia, glucosuria and various concomitant clinical and biochemical symptoms, as well as a high risk of early death (Turk et al., 2012). There are three major types of diabetes: type 1, type 2 and gestational diabetes (American Diabetes Association, 2012). Type II diabetes is characterized by a progressive worsening in secretion functions of the produced insulin and the development of peripheral resistance to insulin, rather than a deficit in insulin production (Turk et al., 2012).

Recent studies showed that there might be a relationship between diabetes mellitus and newly discovered hormone obestatin (Ren et al., 2009).

Obestatin is a 23 - amino acids amidated peptide hormone, and was identified recently as a product of the posttranslational processing of preproghrelin encoded by the ghrelin (GHRL) gene (Zhang et al., 2005).It is predicted to yield two peptides, ghrelin and obestatin. The word obestatin is a contraction of obese, and it is derived from Latin "obedere", meaning "to devour" and "statin", denoting "suppression" (Zhang et al., 2005). It was originally reported to be the ligand for the G-protein coupled receptor 39 (GPR-39) (Zhang et al., 2005, 2008; Dong et al., 2009).

Obestatin is mainly produced in the stomach (Zhang et al., 2005; Stengel and Tache, 2012), plasma (Bang et al., 2007), adipose tissue (Granata et al., 2012) and different peripheral tissues (Gronberg et al., 2008; Ren et al., 2009).

Obestatin has been reported to reduce food intake, body weight gain, gastric emptying, jejunal and duodenum motility (Lagaud et al., 2007; Fujimiya et al., 2010; Lacquaniti et al., 2011; Fujimiya et al., 2012).

Some studies showed that obestatin promotes the survival of $\beta$-cells and stimulates the expression of the main regulatory $\beta$-cell genes, and insulin biosynthesis (Granata et al., 2008). It inhibits glucose induced insulin secretion (Ren et al., 2008), prevents lypolysis and acts similarly to insulin, reduced insulin resistance and reduced adipocyte, inflammation in metabolic tissue. These functions provide evidence of a noval role for obestatin in adipocyte function and glucose metabolism which suggest potential therapeutic perspectives in insulin resistance and metabolic dysfunctions (Granata et al., 2012). Also, obestatin increases adiponectin hormone. Adiponectin is an adipokine specially secreted by adipocytes (Chen et al., 2012 ; Granata et al., 2012) known to improve insulin sensitivity by increasing energy expenditure and fatty acid oxidation. Individuals with type II diabetes mellitus often exhibited decreased adiponectin levels, and insulin sensitivity is improved by adeponectin therapy (Kadowaki et al., 2006).

\section{Aim of the research}

Since there are no previous studies in Iraq about obestatin hormone, so it was suggested to study control and diabetic patients (Type I and II) and the relationship between obestatin hormone and some biochemical parameters.

\section{MATERIALS AND METHODS}

This study included (70) healthy subjects ( 34 female, 36 male), with age matching to the patients group as control. Seventy five patients (41 female, 34 male) with diabetes 
mellitus from al-waffaa center for diabetic patients in Mosul city; were included in this study and divided into two subgroups:

Sub group I: (25) patients from both sexes and their ages range between (less or equal to 15) years old and (16-34) years old with type I diabetes mellitus.

Sub group II: (50) patients from both sexes and their ages range (35-44) years old, (4554) years old and (equal or over than 55) years old with type II diabetes mellitus.

Fasting blood samples were taken and the serum was separated and used to estimate the following biochemical parameters.

1-Obestatin hormone was measured by enzyme linked immunosorbent assay (ELISA) technique (Cupping and Dongmei, 2009) using CUSABIO kit (China).

The analysis was performed in the immunity laboratory in Al-Salam hospital in Mosul city using BIO-TEK INSTRUMENTS, INC, USA.

2- Adiponectin hormone was measured by enzyme linked immunosorbent assay (ELISA) technique (Ouchi et al., 2004), using USBIOLOGICAL kit (USA). This analysis was performed in the immunity laboratory in Al-Salam hospital in Mosul city.

3- Insulin hormone was measured By ELISA technique (Kahn and Rosenthal, 1979), using Monobind kit (USA). The analysis was performed in the immunity laboratory in the department of biology, College of Science, University of Mosul using (Labtech), UK.

4-Blood glucose was determined by the enzymatic colorimetric method (Trinder, 1969), using BIOLABO kit (France).

5-Homeostasis model assessment of insulin resistance (HOMA-IR) was calculated from fasting insulin and glucose by the following equation:

HOMA $-\mathrm{IR}=$ Insulin $(\mu \mathrm{U} / \mathrm{ml}) \times$ Glucose $(\mathrm{mmol} / \mathrm{L}) / 22.5$ (Matthews et al., 1985).

6-Total lipids was determined manually by colorimetric method (Chabrol and Chardonnet, 1937).

7-Total proteins was determined by biuret method (Grandall, 1983), using BIOLABO kit (France).

8-Albumin was determined by Bromocresol Green Method (Doumas et al., 1971), using BIOLABO kit (France).

9-Globulin was calculated by following the equation:

Globulin conc. $=$ Total protein conc. - Albumin conc. (Richterich, 1969).

10- Total cholesterol was determined by the enzymatic colorimetric method (Allain et al., 1974), using BIOLABO kit (France).

11- Triglycerides was determined by enzymatic colorimetric method (Fossati and Prencipe, 1982) using BIOLABO kit (France).

12- High density lipoprotein-cholesterol (HDL-C) was determined by precipitation method (Lopez-Virella et al., 1977), using BIOLABO kit (France).

13- Low density lipoprotein-cholesterol (LDL-C) was calculated using the following equation:

LDL-C $(\mathrm{mmol} / \mathrm{L})=$ Total Cholesterol conc. - HDL-C - TG conc. / 2.2 (Burtis and Ashwood, 1982).

14- Very low density lipoprotein-cholesterol (VLDL-C) was calculated using the following equation:

VLDL conc. $(\mathrm{mmol} / \mathrm{L})=\mathrm{TG}$ conc. $(\mathrm{mmol} / \mathrm{L}) / 2.2$ (Fischbach, 2000). 
The weight and height were also measured and the body mass index (BMI) calculated as weight in kilogram divided by the square height in meters (Harvey et al., 2011).

\section{DATA ANALYSIS}

The data obtained in the current study were analyzed using Statistical Package for Social Sciences (SPSS)

1. Standard statistical methods were used to determine the mean and standard error.

2. T-Test was used to compare between two parameters.

3. One way Anova (Duncan-test) is used to compare between more than two parameters.

4. Linear regression analysis [Pearson correlation coefficient (r)] was performed to identify the relationship between different biochemical parameters.

5. P-Value $\leq 0.05$ was considered to be statistically significant (Kirkwood, 1988)

\section{RESULTS AND DISCUSSION}

The results (Table 1) showed that the normal mean level of obestatin hormone is $(306.54 \pm 3.0 \mathrm{pg} / \mathrm{ml})$ in control. This was approximate to the results showed by others (Lippl et al., 2008; Zamrazilova et al., 2008), where they showed that the concentration of obestatin in normal subjects was $(298.7 \mathrm{pg} / \mathrm{ml})$ and $(267.9 \mathrm{pg} / \mathrm{ml})$ respectively.

Table 1: The concentration of obestatin hormone in control and diabetic patients according to age and sex

\begin{tabular}{|c|c|c|c|c|c|c|}
\hline \multirow{3}{*}{$\begin{array}{c}\text { Age } \\
\text { (year) }\end{array}$} & \multicolumn{6}{|c|}{ Concentration of obestatin hormone $(\mathrm{pg} / \mathrm{ml})$ mean \pm S.E } \\
\hline & \multicolumn{2}{|c|}{ Control group } & \multicolumn{2}{|c|}{ Type I Diabetes } & \multicolumn{2}{|c|}{ Type II Diabetes } \\
\hline & Male & Female & Male & Female & Male & Female \\
\hline$\leq 15$ & $293.31 \pm 16.06$ & $329.69 \pm 17.89$ & $257.67 \pm 7.02$ & $268.41 \pm 8.03$ & & \\
\hline 16-34 & $306.84 \pm 7.93$ & $326.54 \pm 10.96$ & $258.27 \pm 6.22$ & $255.5 \pm 7.48$ & & \\
\hline $35-44$ & $295.53 \pm 8.07$ & $305.66 \pm 5.58$ & & & $223.82 \pm 11.14$ & $238.81 \pm 10.97$ \\
\hline 45-54 & $298.65 \pm 7.11$ & $308.70 \pm 4.62$ & & & $221.50 \pm 9.64$ & $226.28 \pm 11.21$ \\
\hline$\geq \mathbf{5 5}$ & $294.40 \pm 13.2$ & $307.55 \pm 5.44$ & & & $229.03 \pm 11.31$ & $236.23 \pm 11.08$ \\
\hline $\begin{array}{c}\text { Total } \\
\text { mean } \pm \\
\text { S.E }\end{array}$ & \multicolumn{2}{|c|}{$306.54 \pm 3.0$} & \multicolumn{2}{|c|}{$* 259.897 \pm 3.49$} & \multicolumn{2}{|c|}{$* * 229.56 \pm 4.34$} \\
\hline
\end{tabular}

*Significant difference at $\mathrm{p} \leq 0.05$,

\section{Obestatin concentration level in diabetic patients compared to control:}

The data in Table (1) showed that diabetic patients (Type I and II) have a significantly lower obestatin level compared to control. The table also showed that there was a significant lower of obestatin concentration in type II diabetic patients compared to type I diabetic patients. Thes indicates the major role of obestatin in type II diabetic patients. These results 
were in agreement with those obtained hormone by others (Qi et al., 2007; Lippl et al., 2008). The cause of these decreases in type II diabetic patients might due to the obestatin role in appetite regulation ( Qi et al., 2007) or might be also due to the increase of BMI and insulin resistance in type II diabetic patients (Cuiping and Dongmei, 2009). The cause might be due to the decrease of GPR-39 level in obese type II diabetic patients (Catalan etal., 2007), but the cause of the decreases of obestatin in type I compared to control might be due to the insulin and the whole body insulin sensitivity could be regulate the obestatin secretion (Anderwald et al., 2007). Furthermore, obestatin positively correlated to insulin concentrations and its actions (Chanoine et al., 2006).

\section{Obestatin concentration level in diabetic patients compared to control group according to the age and sex:}

The results in (Table 1) showed that there were no significant differences in obestatin between males and females among diabetic patients (type I and II) groups and control group. These results were in agreement with those found by others (Guo et al., 2007). The table also demonstrates that there was no significant difference in obestatin according to age groups in diabetic patient (Type I and II) and control. These results were in agreement with those obtained by (Lippl et al., 2008).

\section{Obestatin concentration level in diabetic patients compared to control according to BMI:}

The data in (Table 2) showed that there was a significant gradual decrease of obestatin in control and type II diabetic patients as BMI increases. These results were in agreement with those performed by others (Zamrazilova et al., 2008; Zhang et al., 2011), which they found that obestatin decreases in obese groups compared to normal ones. Furthermore, obestatin negatively correlated with BMI (Guo et al., 2007; Lippl et al., 2008), which might be due to biopsy studies which reduced the number of obestatin cells in the gastric body mucosa of these individuals (Gao et al., 2010). Also might be supported the hypothesis that obestatin and ghrelin interact with each other, and the balance between them might play a role in the regulation of body weight (Zhang et al., 2011).

On the other hand, other investigators found that obestatin and ghrelin release is differentially regulated by meal intake in lean individuals. This regulation is impaired in obesity (Maier et al., 2010).

The results in (Table 2) also showed that type II diabetic patients have a significantly lower obestatin as compared to type I diabetic patients and control when matched for BMI. These results were in agreement with those found by other investigators (Qi et al., 2007; Cuiping and Dongmci, 2009). The results also demonstrate that type I diabetic patients have a significantly lower obestatin concentration compared to control. 
Table 2: The concentration of obestatin hormone in control and diabetic patients according to BMI

\begin{tabular}{|c|c|c|c|}
\hline \multirow{2}{*}{ BMI kg/m } & \multicolumn{3}{|c|}{ Concentration of obestatin (pg/ml) mean \pm S.E } \\
\cline { 2 - 4 } & Control group & Type I Diabetes & Type II Diabetes \\
\hline$\leq \mathbf{2 5 n o r m a l}$ weight & $329.30 \pm 4.55$ & $* 267.91 \pm 1.93$ & $* 248.83 \pm 2.93$ \\
\hline $\mathbf{2 6 - 2 9}$ over weight & $* 309.83 \pm 1.02$ & $* 242.95 \pm 6.229$ & $* 216.26 \pm 1.97$ \\
\hline $\mathbf{2 3 0}$ obese & $* 281.21 \pm 3.69$ & & $* * 198.33 \pm 1.52$ \\
\hline
\end{tabular}

*Significant difference at $\mathrm{p} \leq 0.05$.

** Significant difference at $\mathrm{p} \leq 0.01$.

4. Obestatin concentration level in diabetic patients according to the blood glucose concentration:

In order to find relationship between obestatin concentration and glucose concentration, the groups of diabetic patients were divided according to the concentration of glucose into three levels as shown in (Table 3).

Table 3: The concentration of obestatin hormone in diabetic patients according to glucose concentration

\begin{tabular}{|c|c|c|}
\hline \multirow{2}{*}{$\begin{array}{c}\text { Glucose conc. } \\
\text { mmol/L }\end{array}$} & \multicolumn{2}{|c|}{ Concentration of obestatin $(\mathbf{p g} / \mathbf{m l})$ mean \pm S.E } \\
\cline { 2 - 3 } & Type I Diabetes & Type II Diabetes \\
\hline $\mathbf{6 . 2 - 1 0}$ & $268.06 \pm 3.65$ & $260.03 \pm 3.41$ \\
\hline $\mathbf{1 0 . 1 - 1 4}$ & $246.44 \pm 3.67$ & $219.79 \pm 3.65$ \\
\hline $\mathbf{1 4 . 1 - 2 0}$ & $* 212.40 \pm 5.45$ & $* 194.31 \pm 0.93$ \\
\hline
\end{tabular}

*Significant difference at $\mathrm{p} \leq 0.05$.

The results in Table (3) demonstrate that there was a significant gradual decrease of obestatin in type I and II diabetic patients as the concentration of glucose increases. This might be due to the role of obestatin in enhancing glucose uptake in either the absence or presence of insulin and also due to the effect of obestatin in reducing insulin resistance, increasing insulin secretion from pancreatic islets (Granata et al., 2012) and upregulating glucokinase expression (Granata et al., 2008).

The concentration of some biochemical parameters in control and diabetic patients:

The research also involves an estimation of some biochemical parameters in diabetic patients compared with control to find the relationship between obestatin and some biochemical parameters as shown in Table (4). 


\section{Adiponectin concentration level in diabetic patients compared to control}

The data in Table (4) demonstrate that type I diabetic patients have a significantly higher concentration of adiponectin compared to type II diabetic patients and control. These results were in agreement with results found by others (Leth et al., 2008). The cause might due to insulinś effect on adiponectin synthesis and secretion, where the insulin regulates adiponectin synthesis in vitro (Fasshauer et al., 2002). Therefore, it is possible that insulin deficiency in patients with type I diabetes might be associated with an increase adiponectin synthesis.

The data also demonstrate that type II diabetic patients have a significantly lower adiponectin compared to control. These results were in agreement with those obtained by others (Kadowaki et al., 2006). The cause might be due to insulin that regulates adiponectin mRNA expression. It has been proposed that hyperinsulinemia, which is associated with insulin resistance in type II diabetic patients, might be responsible for the decrease in serum adiponectin.

\section{Homeostasis model assessment insulin resistance (HOMA-IR) in diabetic patients compared to control}

There was no significant difference of HOMA-IR between type I diabetic patients and control, but there was a significant difference between type II diabetic patients compared with control and type I diabetic patients as shown in Table (4). These results were in agreement with those found by others (Bakari and Onyemelukwe, 2005). The cause of that might be attributed to the increase of glucose and insulin levels in type II diabetic patients which is related to obesity.

The values of insulin conc., glucose, cholesterol, triglyceride, HDL-C, VLDL-C, LDL$\mathrm{C}$, total lipids conc., and blood proteins were listed in (Table 4). These values were similar to what were obtained in literature and can be used for correlation studies with obestatin.

\section{Correlation between the concentration of obestatin hormone and some biochemical parameters in control and diabetic patients.}

The results in (Table 5) demonstrated that there was a positive correlation between obestatin and adiponectin in control and diabetic patients (type I and II). The cause might be attributed to that the obestatin induced adiponectin in adipose tissue because obestatin reduced insulin resistance and improved insulin sensitivity (Granata et al., 2012). On the other hand, there was a negative correlation between obestatin and insulin in type II diabetic patients. These results were in agreement with the results found by others (Lippl et al., 2008; Zamrazilova et al., 2008; Cuiping and Dongmei et al., 2009). The cause might be due to that obestatin inversely correlated to insulin resistance in type II diabetic patients and to increasing BMI. 
Table 4: The concentration of some biochemical parameters in control and diabetic patients

\begin{tabular}{|c|c|c|c|}
\hline \multirow{2}{*}{$\begin{array}{l}\text { Biochemical } \\
\text { Parameters }\end{array}$} & \multirow{2}{*}{$\begin{array}{l}\text { Control } \\
\text { mean } \pm \text { S.E }\end{array}$} & \multicolumn{2}{|c|}{ Diabetic Patients } \\
\hline & & $\begin{array}{c}\text { Type I } \\
\text { Mean } \pm \text { S.E }\end{array}$ & $\begin{array}{c}\text { Type II } \\
\text { Mean } \pm \text { S.E }\end{array}$ \\
\hline Adiponectin $\mu \mathrm{g} / \mathrm{ml}$ & $11.38 \pm 0.31$ & ${ }^{*} 19.04 \pm 0.38$ & $4.57 \pm 0.23$ \\
\hline Insulin $\mu \mathrm{u} / \mathrm{ml}$ & $10.01 \pm 0.16$ & ${ }^{*} 4.11 \pm 0.16$ & $9.88 \pm 0.42$ \\
\hline Glucose mmol/L & $5.07 \pm 0.25$ & *11.69 10.81 & $10.54 \pm 0.44$ \\
\hline HOMA-IR & $2.16 \pm 0.05$ & $1.88 \pm 0.1$ & "4.53 \pm 0.27 \\
\hline Cholesterol mmol/L & $4.87 \pm 0.13$ & $5.96 \pm 0.16$ & $6.58 \pm 0.08$ \\
\hline Triglyceride $\mathrm{mmol} / \mathrm{L}$ & $1.42 \pm 0.05$ & $2.28 \pm 0.05$ & $2.92 \pm 0.06$ \\
\hline VLDL-C mmol/L & $0.28 \pm 0.01$ & $0.46 \pm 0.02$ & $0.58 \pm 0.01$ \\
\hline LDL-C mmol/L & $3.32 \pm 0.13$ & $4.59 \pm 0.24$ & $5.12 \pm 1.31$ \\
\hline HDL-C mmol/L & $1.21 \pm 0.02$ & $0.88 \pm 0.06$ & $0.91 \pm 0.04$ \\
\hline Total Lipids mg/dL & $688.4 \pm 8.04$ & $777.88 \pm 11.82$ & $841.78 \pm 8.28$ \\
\hline Total proteins $\mathrm{g} / \mathrm{L}$ & $71.75 \pm 0.97$ & $62.87 \pm 0.72$ & $68.1 \pm 0.72$ \\
\hline Albumin g/L & $41.33 \pm 0.42$ & $39.91 \pm 0.37$ & $36.26 \pm 0.36$ \\
\hline Globulin g/L & $30.44 \pm 0.46$ & $23.33 \pm 0.45$ & $31.84 \pm 0.37$ \\
\hline
\end{tabular}

On the other hand, the results also demonstrate that there was a significant negative correlation between obestatin hormone and glucose in type I and II diabetic patients and control. These results are in agreement with those found by other investigators (Guo et al., 2007; Qi et al., 2007; Cuiping and Dongmei, 2009). The cause might be due the effect of obestatin in improving the sensitivity and secretion of insulin and the enhancement of glucose uptake in either the absence or presence of insulin (Granata et al., 2012). Also obestatin promotes $\beta$-cell and human islet cell survival and stimulates the expression of main regulatory $\beta$-cell genes (Granata et al., 2008).

Moreover, there was a negative correlation between obestatin and insulin resistance (HOMA-IR) in diabetic patients (Type I and II) and control. These results are in agreement with those done by others (Cuiping and Dongmei, 2009). The cause might be due to the decrease of obestatin concentration when BMI and glucose level increases. 
Table 5: The correlation between obestatin hormone and biochemical parameters in controls and type 1 and type 2 diabetes

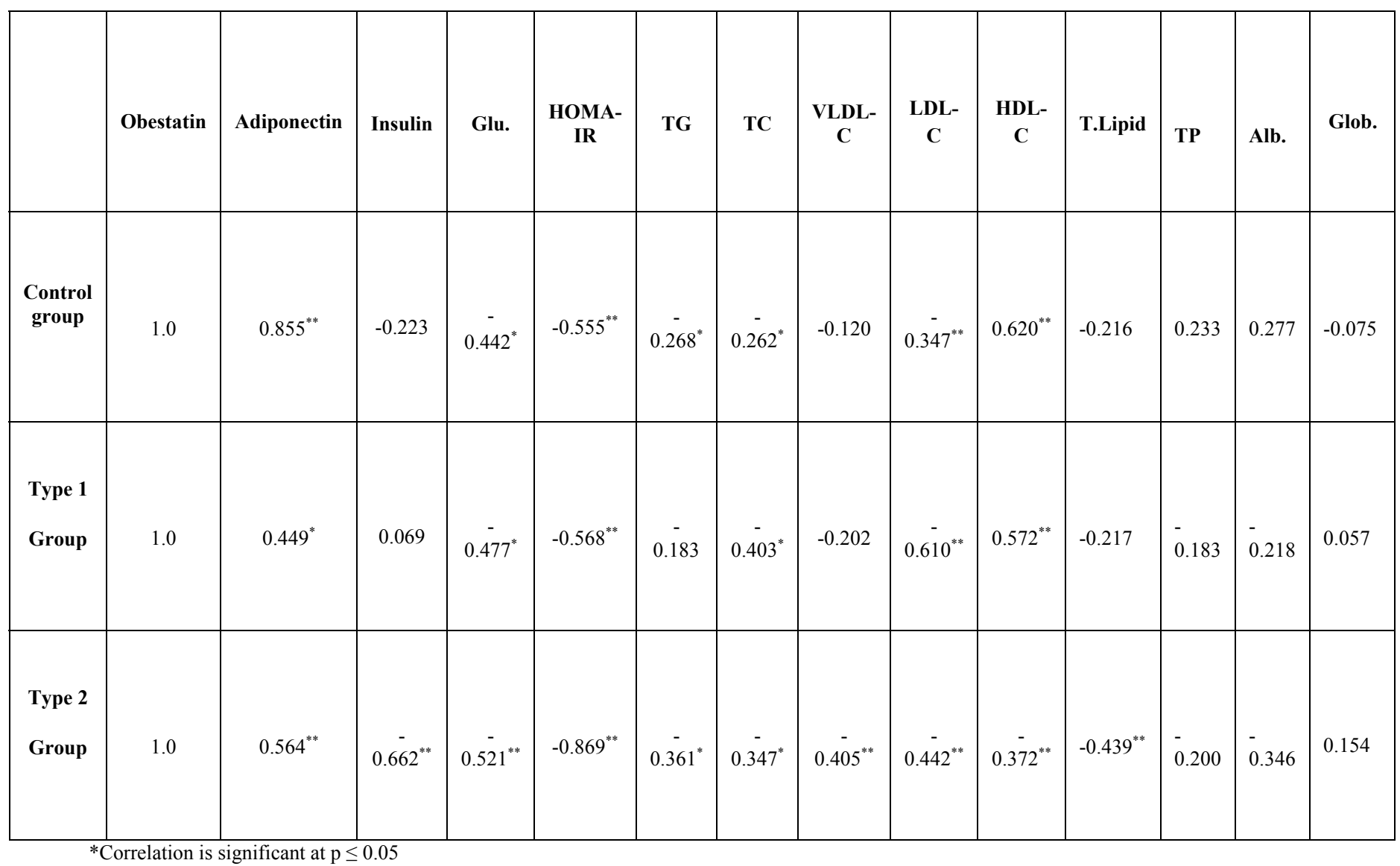


Moreover, the results in (Table 5) showed that there was a significant negative correlation between obestatin and cholesterol in diabetic patients (type I and II) and control. The cause might be due to that obestatin increases the phosphorylation of AMP-activated protein kinase (Granata et al., 2012) and this will inhibit the synthesis of 3-hydroxy3methyl glutaryl-CoA reductase (HMG-CoA reductase) which contributes in the biosynthesis of cholesterol.

The results in Table (5) also, demonstrate that there was a significant negative correlation between obestatin and triglyceride in type II diabetic patients and control . The cause might be due to that obestatin promotes AMP-activated protein Kinase (Granata et al., 2012) and this will inhibit acetyl CoA carboxylase which contribute in the biosynthesis of fatty acid and triglyceride (King, 2012) .

Furthermore, there was a significant positive correlation between obestatin and HDL-C in diabetic patients (Type I and II) and control.

The results of other investigators (Ander Wald-Stadler et al., 2007) have supported our results. The cause might be due to that obestatin stimulates insulin secretion, so the activity of lipoprotein lipase will increase and lead to increase HDL-C, or the cause might be due to that obestatin promote adiponectin which correlated positively with HDL-C (Hsu et al., 2012).

The data in (Table 5) also showed that there was a significant negative correlation between obestatin and LDL-C in control and diabetic patients (Type I and II). Also, the results showed that there was a significant negative correlation between obestatin and 
VLDL-C in type II diabetic patients. The cause might be due to that obestatin increases the phosphorylation of AMPK (Granata et al., 2012) and this inhibit acetyl CoA carboxylase which contribute in biosynthesis of fatty acid and lead to increase LDL-C and VLDL-C. Adinosine monophosphate activated protein kinase(AMPK) also increased fatty acid oxidation and inhibition of hepatic lipogensis (Fogarty and Hardie, 2010).

On the other hand, the results showed that there was a significant negative correlation between obestatin and total lipid in type II diabetic patients. The cause might be due to that obestatin prevents lipolysis in adipose tissue and acts similarly to insulin which inhibits the activity of hormone sensetive lipase (Granata et al., 2012).

\section{CONCLUSIONS}

It was concluded that obestatin hormone has a major role in diabetes mellitus (Type I and II), especially in type II diabetes there is relationship with BMI, and could be used as a marker for diabetes and obesity.

\section{REFERENCES}

Allain, C.C.; Poon, L.S.; Chan, C.S.; Richmond, W.; Fu, P.C. (1974). Determination of serum total cholesterol by enzymatic colorimetric method. Clini. Chem., 20(4), 470- 475.

American Diabetes Association (2012). Diagnosis and classification of diabetes mellitus. Diabetes Care, 35 (1), 64-71.

Anderwald-Stadler, M.; Krebs, M.; Promintzer, M.; Mandl, M.; Bischof, M.G.; Nowotny, P.; Kastenbauer, T.; Luger, A.; Prager, R.; Anderwald, C. (2007). Plasma obestatin is lower at fasting and not suppressed by insulin in insulin- resistant humans. Am. J. Physiol. Endocrinol. Metab., 293, 1393-1398.

Bakari, A.G.; Onyemelukwe G. (2005). Insulin resistance in type II diabetic Nigerians. Int. J. Diabetes and Metabolism, 13, 14-27.

Bang, A.S.; Soule, S.G.; Yandle, T.G.; Richards, A.M.; Pemberton, C.J. (2007). Characterisation of proghrelin Peptides in mammalian tissue and Plasma. $J$. Endocrinol., 192, 313-323.

Burtis, C.A.; Ashwood, E.R. (1982). "Tietz Fundamental of Clinical Chemistry". 2nd. ed. W. B. Saunders company, U.S.A., pp. 302, 337, 539, 901.

Catalan, V.; Gomez-Ambrosi, J.; Rotellar, F.; Silva, C.; Gil, M.J.; Rodriguez, A.; Cienfuegos, J.A.; Salvador, J.; Fruhbeck, G. (2007). The obestatin Receptor $\left(\mathrm{GPR}_{39}\right)$ is expressed in human adipose tissue and is down-regulated in obesity-associated type II diabetes mellitus. Clini. Endocrinol., 66 (4), 598-601.

Chabrol; Chardonnet (1937). Cited by Gelson Toro and Philip, G. (1975). "Prac. Clini. Chem." Little, Brown and Company, Boston. 1321p.

Chanoine, J.P.; Wong, A.C.; Barrios, V. (2006). Obestatin acylated and total ghrelin concentrations in the prenatal rat pancreas. Horm. Res., 66, 81-88.

Chen, X.; Scholl, T.O.; Stein, T.P. (2012). Hypoadiponectinemia: Association with risk of varying degrees of gestational hyperglycemia and with materal ethnicity. J. Diabetes Mellitus, 2 (2), 196-202.

Cuping, Z.; Dongmei, K. (2009). Changes of plasma obestatin and ghrelin in diabetes mellitus. Chinese J. Clini. Health Care, 22 (6), 589- 591. 
Dong, X.Y.; He, J.M.; Tang, S.Q.; Li, H.Y.; Jiang, Q.Y.; Zou, X.T. (2009). Is GPR 39 the natural receptor of obestatin. Peptides, 30, 431-438.

Doumas, B.T.; Watson, W.A.; Briggs, H.D. (1971). Albumin standards and the measurement of albumin with bromocresol green. Clini. Chem. Acta., 31, 87-96.

Fasshaure, M.; Klein, J.; Neumann, S.; Eszlinger, M.; Paschke, R. (2003). Hormonal regulation of adiponectin gene expression in 3T3-L1 adipocytes. Biochem. Biophys. Res. Commun., 290, 1084-1089.

Fischbach, F. (2000). "A Manual of Laboratory and Diagnostic Tests". 6th. ed. Lippincott Williams and Wikins, U. S. A., 472 p.

Fogarty, S.; Hardie D.G. (2010). Development of protein kinase activators: AMPK as a target in metabolic disorders and cancer. Biochem. Biophys. Acta., 1804, 581591.

Fossati, P.; Prencipe, L. (1982). Serum triglycerides determined colorimetrically with an enzyme that produces hydrogen peroxide. Clini. Chem., 28 (10), 2077-2080.

Fujimiya, M.; Asakawa, A.; Ataka, K.; Chen, C. Y.; Kato, I.; Inui, A. (2010). Ghrelin, Des-Acyl ghrelin, and obestatin: regulatory roles on the gastrointestinal motility. International J. Peptides, 2010, 192- 200.

Fujimiya, M.; Ataka, K.; Asakawa, A.; Chen, C.Y.; Kato, I. (2012). Regulation of gastroduodenal motility: acyl ghrelin, des-acyl ghrelin and obestatin and hypothalamic peptides. Digestion, 85, 90-94.

Gao, X.Y.; Kuang, H.Y.; Liu, X.M.; Ma, Z.B. (2010). Decreased gastric body mucosa obestatin expression in overweight and obese patients. Peptidase, 31, 291-296.

Granata, R.; Gallo, D.; Luque, R. M.; Baragli, A.; Scarlatti, F.; Grande, C.; Gesmundo, I.; Cordoba-Chacon, J. ; Bergandi, L.; Settanni, F.; Togliatto, G.; Volante, M.; Garetto, S.; Annunziata, M.; Chancclon, B. ; Gargantini, E.; Rocchietto,S.; Matera, L.; Datta, G.; Morino, M.; Brizzi , M.F.; Ong, H.; Camussi, G.; Castano, J.P.; Papotti, M.; Ghigo, E. (2012). Obestatin regulates adipocyte function and protects against diet- induced insulin resistance and inflammation. The FASEB J., 26, 150-73.

Granata, R.; Settanni, F.; Gallo, D.; Trovato, L.; Biancone, L.; Cantaluppi, V.; Nano, R.; Annunziata, M.; Campiglia, P.; Arnoletti, E., Ghe, C.; Volante, M.; Papotti, M.; Muccioli, G.; Ghigo, E. (2008). Obestatin promotes survival of pancreatic beta-cells and human islets and induces expression of genes involved in the regulation of beta-cell mass and function. Diabetes, 57, 967-979.

Grandall, G.D. (1983). "Biochemistry Laboratory". New York, Oxford, University Press, pp. 29- 83.

Gronberg, M.; Tsolakis, A.V.; Magnusson, L.; Janson, E.T.; Saras, J. (2008). Distribution of obestatin and ghrelin in human tissues: immune reactive Cells in the gastrointestinal tract, pancreas, and mammary glands. J. Histo. Chem. Cytochem., 56, 793-801.

Guo, Z.F.; Zheng, X.; Qin, Y.W.; Hu, J.Q.; Chen, S.P.; Zhang, Z. (2007). Circulating preprandial ghrelin to obestatin ratio is increased in human obesity. J. Clini. Endocrinol. Metab., 92, 1875-1880.

Harvey, R.A.; Harvey, R.; Ferrier D. (2011). "Lippincott's Illustrated Reviews: Biochemistry". 5th. ed., Lippincott Williams and Wilkins, N.Y.P. pp.190, 344, 346, 349. 
Hsu, C.H.; Liao, Y.L.; Lin, S.C.; Chou, P. (2012). Adiponectin level predicts HDLcholesterol level in type II diabetes. The Open Atherosclero Sis and Thrombosis J., 5, $1-5$.

Kadowaki, T.; Yamauchi, T.; Kubota. N.; Hara, K.; Ueki, K.; Tobe, K. (2006). Adiponectin and adiponectin receptors in insulin resistance, diabetes, and the metabolic syndrome. J. Clini. Invest., 116, 1784-1792.

Kahn, C.R.; Rosenthal, A.S. (1979). Immunologic reactions to insulin, insulin allergy, insulin resistance and autoimmune insulin syndrome. Diabetes Care, 2, 283-295.

Kirkwood, B.R. (1988). Essentials of Medical Statistics. 1st ed., Black well Scientific Publication, Oxford; pp. 43-56.

Lacquaniti, A.; Donato, V.; Chirico, V.; Buemi, A.; Buemi, M. (2011). Obestatin: an interesting but controversial gut hormone. Annals. Nutrition and Metabolism, 59, 93199.

Lagaud, G.J; Young, A.; Acena, A.; Morton, M.F.; Barrett, T.D.; Shankley, N.P. (2007). Obestatin reduces food intake and suppresses body weight gain in rodents. Biochem. Biophys. Res. Commun., 357, 264-269.

Leth, H.; Andersen, K.; Frystyk, J.; Tarnow, L.; Rossing, P.; Parving, H.; Flyvbjerg, A. (2008). Elevated levels of high-molecular-weight adiponectin in type 1 diabetes. J. Clini. Endocrinol. and Metabolism, 93 (8), 3186-3191.

Lipple, F.; Erdmann, J.; Lichter N. Tholl, S.; Wagenpfeil S.; Adam O.; Schusdziarra V. (2008). Relation of plasma obestatin levels to BMI, gender, age and insulin. Horm. Metab. Res., 40, 806-812.

Lopez-Verella, M. F.; Stone, P.; Ellis, S.; Glwell, J. A. (1977) Cholesterol determination in high density lipoprotein separated by three different methods. Clini. Chem., 23, 882884.

Maier, C.; Riedl, M.; Vila, G.; Wolzt, M.; Clodi, M.; Ludvik, B.; Luger, A. (2010). Differential regulation of plasma obestatin and ghrelin by meal intake and the cholinergic system in lean, but not obese individuals. J. Clini. Endocrinol. Metab., 95 (10), 214-218.

Matthews, D. K.; Hosker, J. P.; Rudensk, A. S.; Naylor, B. A; Treacher, D. F; Turner, R.C. (1985). Homeostasis model assessment: insulin resistance and beta-cell function from fasting plasma glucose and insulin concentration in man. Diabetologia, 28, 412-419.

Ouchi, N., Kobayashi, H.; Kihara, S.; Kumada, M.; Sato, K.; Inoue, T.; Funahashi, T.; Walsh, K. (2004). Adiponectin stimulates angiogenesis by promoting cross-talk between AMP-activated Protein kinase and Akt signaling in endothelial cells. J. Biol. Chem., 279, 1304-1309.

Qi, X.; Li, L.; Yang, G.; Liu, J.; Li, K.; Tang, Y.; Liou, H.; Boden, G. (2007). Circulating obestatin levels in normal subjects and in patients with impaired glucose regulation and type 2 diabetes mellitus. Clini. Endocrinol. (oxf), 66, 593-597.

Ren, A.J.; Guo, Z.F.; Wang, Y. K.; Wang, L.G.; Wang, W.Z.; Line, Li; Zheng, X.; Yuan, W.J. (2008). Inhibitory effect of obestatin on glucose- induced insulin secretion in rats. Biochem. Biophys. Res. Commun., 369, 969-972.

Ren, A. J.; Guo, Z.F.; Wang, Y.K. (2009). Obestatin, obesity and diabetes. Peptides, 30, 439-444. 
Richterich R. (1969). "Clinical Chemistry Theory and Practice". S. Karger A. G., Basel, Switzerland, pp. 245-249.

Stengel, A.; Tache, Y.V. (2012). Yin and Yang-the Gastric X/A-like cell as possible Dual regulator of food intake. J. Neurogatroenterol. Motil, 18 (2), 138-149.

Trinder, P. (1969). Determination of glucose in blood using glucose oxidease with an all ernative oxygen occeptor. Ann. Clini. Biochem., 6, 24-33.

Turk, N.; Dagistanli, F.K.; Sacan, O.; Yanardag, R.; Bolkent, S. (2012). Obestatin and insulin in pancreas of newborn diabetic rats treated with exogenous ghrelin. Acta Histochemica, 114 (4), 349-357.

Zamrazilova, H.; Hainer, V.; Sedlackova, D.; Papezova, H.; Kunesova, M.; Bellisle, F.; Hill, M.; Nedvidkovo, J. (2008). Plasma obestatin levels in normal weight obese and anorectic women. Physiol. Res., 57, 49-55.

Zhang, J.V.; Jahr, H.; Luo, C.W.; Klein, C.; Van Klein, K.; Ver Donk, L.; De, A.; Baart, E.; Li, J.; Moechars, D.; Hsueh, A.J. (2008). Obestatin induction of early-response gene Expression in gastrointestinal and adipose tissues and the mediatory role of G Protein-coupled receptor, GPR39. Mol. Endocrinol. 22, 1464-1475.

Zhang, J.V.; Ren, P.G.; Avsian -Kretchmer, O.; Luo, C.W.; Rauch, R.; Klein, C.; Hsueh, A. J. (2005). Obestatin, a peptide encoded by the ghrelin gene, opposes ghrelin's effects on food intake. Science, 310, 996-999.

Zhang, N.B.; Yuan-Chao, M. D.; Li-Z. B.; Li, J. B.; Li, X. B.; Li, C. E.; Li, R. B.; Wang, S. R. (2011). Meta-analysis of the Relationship between obestatin and ghrelin levels and the ghrelin / obestatin ratio with respect to obesity. American J. Medical Sci., 341,48-55. 
------ Raf. J. Sci., Vol. 24, No.4 pp. 61-74, $2013-----$ 